\title{
Left and Right in the Blogosphere: Ideological Differences in Online Campaigning
}

\author{
Joachim Åström and Martin Karlsson \\ Örebro University, Örebro School of Public Affairs, Fakultetsgatan 1, \\ 70182 Örebro, Sweden \\ \{joachim.astrom, martin.karlsson\} @oru.se
}

\begin{abstract}
This article investigates the usage of blogs in electoral campaigns in Sweden, a country characterized by strong political parties and a party centered form of representative democracy. The central argument is that blogs are utilized in different ways by different parties. The empirical analysis based on a survey among over 600 blogging politicians indicates a vast difference in uptake and usage of blogs between the right- and left wing politicians. The results indicate that ideological positions towards individualism and collectivism matters for the practice of blogging.
\end{abstract}

Keywords: Blogging, political parties, election campaigns, political individualism.

\section{Introduction}

There is little doubt that the internet is capable of transforming the mode and content of mass communication, perhaps most notably in election campaigning. Political aspirants in the United States, such as Bob Dole, Howard Dean and, most recently, Barack Obama, have all made headlines for their creative use of the internet to mobilize voters and generate support. Blogging, as a form of e-participation, is particularly recognized as a practice that allows candidates to engage in campaigns more directly and bypass parties to articulate individual opinions, thoughts, feelings, experiences and identities [1, 2]. However, not all countries have nurtured the blogosphere in the same way. Recent research has found that the adoption and use of political blogs, to a large extent, is shaped by institutional setting, i.e. the different roles given to political parties [3, 4]. In political systems where major party endorsement is still crucial to winning a seat, there is little incentive for candidates to openly champion divergent positions.

This article aims to investigate the usage of blogs in electoral campaigns in Sweden, a country characterized by strong political parties and a party centered form of representative democracy. This is where the shadow of party hierarchies is among the darkest in Europe. At the same time, internet use is more developed here than in almost any other country. It is a country of partisans as well as pirates. And, perhaps, it is therefore a country in which interesting intra-national differences can be found. The central argument of this article is that blogs are utilized in different ways by different 
parties. Just as blogging is shaped by how institutions support persons or parties, we propose that political blogging is also shaped by attitudes towards preferential voting, candidate-centered campaigning and, at a more basic level, ideological positions towards individualism and collectivism.

According to Benkler and Shaw [5], prior studies have argued that the left and the right are relatively symmetrical and embody uniform practices. However, few investigations have been conducted on the attitudes of political bloggers, and those that have are focused on small samples of elite bloggers $[1,6,5]$. Since this article draws upon a survey questionnaire of 600 blogging candidates in the run-up to the 2010 Swedish election, it has the potential to uncover new perspectives and knowledge.

\section{The Internet and Political Campaigning}

According to most academic observers, the history of political campaigning creates three distinct phases [7]. The first "premodern", era [7], was characterized by decentralized and staff intensive campaign activities and high levels of party loyalty among voters. In the wake of changes in the media landscape, campaigning evolved towards a second "modern era" characterized by stronger centralization of campaign activities and a stronger focus on party leaders. In recent decades, a new era of campaigning has arisen. The so-called "post-modern era" of political campaigning refers to a mixture of developments with uncertain outcomes. On the one hand, there are signs that campaigns continue to professionalize, with power increasingly centralized in the hands of party elites. On the other hand, local campaign organizations seem to be experiencing a second spring [7], and local candidates have started to employ ICTs to run election campaigns, independent of their parties and the traditional media. This ambiguity is highlighted by Zittel [8], who offers two competing hypotheses regarding the internet's impact on the structure of election campaigns - one "orthodox", one "revisionist". The former perceives the internet as reinforcing the trend toward professionalized and centralized campaigns, allowing parties to target and mobilize groups of voters in more efficient and direct ways. Content is primarily about party program and party image, even though information on these topics may often be distributed "with a personal face" [8]. According to the revisionist view, it is not all that certain that parties are in the driver's seat. Instead, it is argued that the internet is a means for individual candidates to run candidate-centered campaigns, independent of their own parties, attracting as much attention as possible to themselves, rather than to their parties.

Blogs are touted as having the potential to reinvigorate political communication by facilitating decentralization, individualization and interactivity, in line with Zittel's revisionist view. At the same time, an unmistakable tension has arisen between orthodox and revisionist tendencies. According to Wright [1], "a battle is being fought". On one side are candidates trying to make use of the individualistic blog platform. On the other side are parties, trying to carry out professionalized campaigns, controlling their messages and presenting uniform fronts. Blogging candidates are, thus, implicated in a tug of war between two different cultures.

Politicians live in a world of certainty and tribal loyalty which is at odds with the blogging ethos of open-mindedness and knowledge-sharing. As long as politicians are 
expected to be never in doubt and ever faithful to catechismic party messages, their blogging efforts are always likely to look more like simulation than authentic selfexpression [2].

In explanations of how blogging candidates handle this intricate situation, factors related to institutional setting have been most prominent [3,4]. Much less attention has been directed to the fact that a candidate-versus-party emphasis within parties may affect the extent to which candidates distance themselves from their parties and loosen central party control over their campaigns. This is somewhat surprising, considering that previous research emphasizes party affiliation as one of the most important explanations for members' support of different principles of representation [10, 11] and that this is often explained with reference to ideological differences. Holmberg [12], for instance, points to the tradition of collectivism within socialism. For leftist parties, the guiding principle has been party solidarity, while right-wing parties have been influenced by more liberal and individualistic traditions of representation. The left-right axis has also been important when explaining different approaches towards reform proposals that support more candidate-centered electoral systems [13, 14]. Again, parties' positions and arguments have been proven to reflect their ideological views on collectivism and individualism. Nonetheless, theoretical arguments or empirical evidence to support the view that the left and right blogospheres should vary remains in short supply. Instead, prior studies have argued that the left and the right are relatively symmetrical and embody uniform practices [5].

The central argument of this article is that blogs are utilized in different ways by different parties. Just as blogging is shaped by how institutions support persons or parties, we propose that political blogging is shaped by party affiliation and ideological positions on individualism and collectivism. We will also consider that blogging candidates are situated within the blogosphere, as well as the party-sphere, and that the depth of their involvement in these spheres might influence their attitudes and strategies. Along the lines of cultural theory, less party-involvement and more bloginvolvement could be expected to increase the probability of individualized campaigning - and vice versa. Another assumption we will test is that innovations such as blogs spread to an increasingly large group only after a period of time. When a phenomenon is new, it is limited to a relatively small group. From a diffusion perspective, we would, therefore, expect that some groups - including young, highly-educated candidates - are particularly likely to use blogs to individualize their campaigns.

\section{The Swedish Political Context}

Sweden is characterized by strong political parties with a central position in the representative democratic system. Parties have traditionally taken a central role in organizing political representation and electoral campaigns; all candidates are nominated by the political parties, and all representatives are organized in party groups. Thus, local and national party organizations are traditionally most influential in the organization of electoral campaigns in Sweden. Although political parties in Sweden, as in most western democracies, have experienced a weakening public support few signs are apparent that the power of political parties in political assemblies is weakening. 
During the last 40 years, Swedish parties have lost the lion's share of their members, voters have become increasingly mobile between elections and party identification among citizens has strongly decayed [15]. Still, the level of party loyalty among elected representatives has steadily increased during the same period. Almost half of representatives say that they would choose to adhere to party views in a conflict between the (known) views of voters, their own views and the views of their party [11]. At the same time, only 15 percent of voters now say that they identify with a party [15]. The current political climate, thus, resembles the picture painted by Katz and Mair in the middle of the nineties: "The parties are at once stronger, but also more remote; at once more in control, but also less powerful; at once more privileged, but also less legitimate" [16].

In an attempt to revitalize Swedish democracy by strengthening candidates' incentives for seeking personal mandates, a preferential vote was introduced through constitutional reform in the mid-nineties [17]. The reform was a compromise between the Liberals and Moderates, who supported a stronger individual vote, on the one hand, and the Social Democrats and Left Party, who strongly opposed individual voting, on the other [13]. The result was an optional preferential vote, allowing voters to make a preferential choice for one candidate on their party's list. If a candidate on the list received enough votes from his or her constituency to reach a pre-set limit ( $8 \%$ for the national parliament and 5\% for local and regional assemblies), he or she was put at the top of the party list and got the first mandate won by the party in that constituency. The Swedish system for individual votes has been characterized as a weak system of preferential voting that gives candidates increased, but still limited, incentives to conduct personal campaigns and does not challenge the central position of political parties in Swedish democracy [13].

The political parties' opinions regarding the preferential vote are strongly polarized. While political representatives from the Left Party and the Social Democrats resist a strengthened preferential voting system and the Greens are only moderately in favor of it, all the parties in the right bloc are strongly in favor of such a reform [18]. Among skeptical politicians on the left, several arguments for limiting the influence of preferential voting have been made; it was thought to Americanize Swedish democracy, threaten the existence of political parties, give campaign financing a decisive role in elections and undermine intra-party democracy, as well as party cohesion $[25,29]$. Increased opportunities for public control and accountability, as well as greater opportunity to strengthen the relationship between voters and representatives and increase activity among both voters and candidates in election campaigns, were arguments put forward by proponents of a strong preferential vote, especially politicians from the conservative Moderates and the Liberals [14]

Taking the description above as a point of departure, the likelihood of finding individualized campaigning in Sweden should be fairly low. Online campaigning in Sweden would be likely to be collectivistic and party-centered. However, the diffusion of the internet has been shown to have some significance when it comes to campaign strategies [7, 19]. Sweden is one country where internet access is most widely diffused. In 2010, over $85 \%$ of the Swedish population had access to the internet [20]. Hence, Sweden is a country where conflicting forces surround political campaigns. On the one hand, it is a country characterized by a strong party-centered tradition and weak institutional incentives to conduct individualized campaigns. On the other hand, 
it is a country much evolved, in terms of the social and technological developments that encourage individualization. The subject of political blogging appears to be an important arena in which to study these two forces. Blogging politicians are socialized into collectivistic parties and are dependent on party-centered electoral institutions but are also employing individually-oriented technologies.

\section{Methods and Measurements}

This study is based on a web survey sent to the authors of all blogs listed on the political blog-ranking site "Politometern" (www.politometern.se) for which e-mail addresses could be found. The survey was answered by 730 political bloggers. The 604 who were politicians from the seven parties represented in the Swedish national parliament during the parliamentary term 2006-2010 were included in the study. Included respondents were either holding political office at the time of the survey (the study includes Members of the European Parliament, members of the national parliament, local councillors and local board members) or candidates in the 2010 elections. The survey was answered during the two months following the 2010 Swedish election. The empirical material accumulated gives a broad overview of the Swedish political blogosphere and makes it possible to analyze bloggers' background, strategies and behavior, in connection to their blogging. This study is primarily based on quantitative analyses of bloggers' survey responses and positions in the network centrality index. The variables used are presented in the following sections. As dependent variables a set of measurements of individualization among political bloggers are analyzed. The independent variables analyzed in this study can be divided into three categories that correspond with the three areas discussed in the theoretical section: party bond, blog-related variables and social characteristics.

\subsection{Individualism - Collectivism}

First, we investigate bloggers' attitudes to preferential voting and separate supporters of a stronger preferential voting system (Support stronger preferential vote) from other respondents. Second, respondents' motives for using blogging as an instrument in personal election campaigns are investigated by dividing respondents into two categories: those who report that using blogging as an instrument in a personal campaign was a strong motive for blogging during the 2010 election campaign (Strong personal campaign motif) and other bloggers. The third dimension of individualism collectivism - is measured by separating bloggers with an individual focus (Blog focusing on person) from bloggers with a party focus (Blog focusing on party).

\subsection{Party Bond}

Bloggers' party affiliation is divided into two party blocs: left-oriented (the Left Party, the Social Democrats and the Greens) and right-oriented (the Centre Party, the Liberals, the Christian Democrats and the conservative Moderates). Level of party activity is operationally defined as the number of party meetings respondents reported having attended during the year preceding the survey (10 party meetings or more/less than 10 party meetings). We also analyze bloggers' positions within their parties by 
separating incumbents, who held a political position in the last parliamentary term, from challengers, who were candidates in the 2010 election and had not held a political position during the last term.

\subsection{Blog-Related Variables}

Level of experience and activity in the blogosphere are investigated using three variables. First, how long respondents have blogged is studied using a variable that separates bloggers with at least two years of experience (Long-time bloggers) from other bloggers (Short-time bloggers). Second, we operationalize level of blogging activity with a variable that reflects the frequency with which bloggers write blog posts, dividing bloggers into two categories: those that update their blogs at least three to five times a week (Frequent bloggers) and those who write posts less frequently. We also investigate level of activity in the blogosphere by creating two categories for respondents who read others' blogs: those who follow ten blogs or more (Heavy blog readers), and those who follow fewer than ten blogs.

\subsection{Social Characteristics}

Several social characteristics are analyzed: gender (Man/Woman); education - specifically, whether or not respondents have a post-secondary school education (High education/Low education); age - specifically, whether respondents are born before or after 1970 (Under 40 years old / 40 years or older).

\section{Empirical Analysis}

\subsection{Who Are Swedish Political Bloggers?}

The distribution of political, social and blogging variables reveals many similarities between the left and right blogosphere in the run-up to the 2010 Swedish election, but there are some interesting differences, as well. Perhaps most important, there seems to be an ideological bias towards the right. First, the data show that bloggers from the right are somewhat overrepresented among respondents (352, against 252). Second, a general right orientation of the Swedish political blogosphere becomes evident when comparing left-right self-positioned blogging politicians ${ }^{1}$ to other Swedish politicians. A majority of bloggers are in harmony with their parties, in the sense that they position themselves at the mean self-positioning value among political representatives from their parties $[33]^{2}$. However, while only $11 \%$ of bloggers position themselves to the left of their parties, a quarter of bloggers position themselves to the right - a tendency which is greatest for bloggers on the left (Table 1). Moreover, the mean self-

\footnotetext{
${ }^{1}$ We investigate self positioning on an eleven-point scale, reaching from 0 (most left-oriented) to 10 (most right-oriented), that is included in several earlier studies of Swedish politicians and voters (see [33] for an overview).

${ }^{2}$ The results of the blog survey are compared with a survey among political representatives in Sweden. The party mean values from the general survey presented are rounded to the closest whole number, Left $=1$, Social democrats $=3$, Greens $=4$, Centre party $=6$, Liberals $=6$, Christian democrats $=7$, Conservative moderates $=8$.
} 
position on the left-right scale among all bloggers is 6,3 when individual positions are weighted against their respective parties' share of seats in national, regional and local assemblies. In comparison to surveys of Swedish representatives, the political bloggers in this study are, in general, remarkably more right-oriented. Surveys among Swedish politicians in general shows that representatives at both the local and regional levels had a mean left-right position of 4,8 , while national representatives positioned themselves more to the right and had a mean value of 5,2 [18]. Thus, the blogosphere during the 2010 Swedish election cycle shows an ideological bias towards the right. Blogging more often attracts candidates to the right of the ideological spectrum, both between and within parties.

Table 1, furthermore, shows that candidates from both the left and the right are highly involved in the party-sphere, as well as the blogosphere. More than $80 \%$ of respondents' have participated in ten or more party meetings during the last year, and a third of blogging politicians hold incumbent positions. The remaining two-thirds were candidates in the 2010 elections. A large share of respondents is also comprised of highly active and experienced bloggers. The majority had blogged for more than two years before the 2010 Swedish elections, and almost a third wrote daily blog posts during the election campaigns. Respondents are also active as readers of political blogs: about a fifth follows ten or more political blogs, and over 40 percent follow between four and ten. No major differences are visible between left- and rightoriented bloggers when it comes to frequency of writing or reading blog posts. However, a significantly higher number of bloggers from leftist parties have been blogging for two years or more.

When it comes to social characteristics, we find that blogging candidates are predominantly male, representing six out of ten respondents. This difference roughly reflects the gender difference among local and regional Swedish politicians, in general (42\% women) but is somewhat higher than the gender differences among national parliamentarians (47\% women) [19]. The share of female political bloggers is slightly higher among the left-oriented than the right-oriented parties. As we would expect, the age structure among bloggers is different from that of politicians, in general. Young politicians are overrepresented among bloggers, but there is, nonetheless, a fairly high number of bloggers over the age of 40. There is a significant difference in age structure between the two party groups, as left-oriented bloggers are more often under forty. No similar difference is apparent among left and right politicians, in general [19].

\subsection{Political Blogging, Collectivism and Individualism}

Let us turn from the backgrounds of blogging candidates to the question of how and why they blog. A key finding in our survey (Table 2) is that blogging politicians on the right are much more individualized than those on the left, who are more strongly tied to the collective identities of their parties. While more than two-thirds of bloggers from parties on the right support a "stronger personal vote" in the Swedish election system, only a quarter of bloggers on the left do the same. Almost two-thirds of rightoriented bloggers display a strong personal campaign motive for blogging, compared to only a fifth of bloggers on the left. Additionally, $43 \%$ of blogging politicians on the right report that they focus more on themselves than on their parties in their blogs. 
Table 1. The Swedish candidate blogger; left and right (percentages)

\begin{tabular}{|c|c|c|c|c|}
\hline & All & Left & Right & Difference \\
\hline Incumbent position (elected) & 32 & 29 & 33 & 4 \\
\hline Challenger position (not elected) & 68 & 71 & 67 & -4 \\
\hline Visited 10 or more party meetings & 81 & 81 & 81 & 0 \\
\hline Visited less than 10 party meetings & 19 & 19 & 19 & 0 \\
\hline Ideologically left of party & 11 & 12 & 9 & -3 \\
\hline Ideologically same as party & 64 & 57 & 69 & $12^{* * *}$ \\
\hline Ideologically right of party & 24 & 29 & 22 & $-7^{* *}$ \\
\hline Long time blogger $>$ two years & 55 & 66 & 46 & $-20^{* * *}$ \\
\hline Short time blogger $<$ two years & 45 & 34 & 54 & $20^{* * *}$ \\
\hline Blogged daily & 29 & 28 & 30 & 2 \\
\hline Blogged weekly & 45 & 44 & 46 & 2 \\
\hline Blogged less often & 26 & 28 & 24 & -4 \\
\hline Follows more than 10 blogs & 18 & 19 & 18 & -1 \\
\hline Follows 4-10 blogs & 43 & 41 & 45 & 4 \\
\hline Follows $0-3$ blogs & 39 & 40 & 38 & -2 \\
\hline Men & 61 & 58 & 63 & 5 \\
\hline Women & 39 & 42 & 38 & -5 \\
\hline Younger than 40 years & 46 & 55 & 44 & $-11^{* *}$ \\
\hline 40 years or older & 54 & 45 & 56 & $11^{* *}$ \\
\hline High education & 72 & 71 & 72 & 1 \\
\hline Low education & 29 & 29 & 28 & -1 \\
\hline $\mathrm{N}$ & 604 & 252 & 352 & 100 \\
\hline
\end{tabular}

Notes: Chi-square test, significance levels are displayed as follows, ${ }^{* * * *}: \mathrm{p}<, 01,{ }^{* * *}: \mathrm{p}<, 05$, *:p<,1.

The comparable figure for bloggers on the left is $20 \%$. This pattern remains strong, even when bloggers are categorized according to political, social and blogging variables. With few exceptions, ${ }^{3}$ significant differences are apparent between left- and right-oriented bloggers, at all levels of individualization in all categories of bloggers. Thus, our findings strongly suggest that the blogosphere plays different roles for the left and right. The right appears to embrace an individualized form of candidatecentered blogging, while the left gives the impression of having a more collective agenda.

Besides ideology, do less party-involvement and more blog-involvement increase the probability of individualized campaigns? Sometimes the evidence points in such a direction, but the results are rather complex. Left and right bloggers with challenger positions and relatively low party activity tend to be more supportive of a stronger personal vote, especially challengers. They also tend to focus somewhat more on

\footnotetext{
${ }^{3}$ Significant differences between bloggers on the left and right are not found regarding the level of focus on person (in comparison to focus on party) for bloggers that attend few party meetings, among female bloggers.
} 
person, rather than party, in their blogs, especially within the left bloc. However, incumbents do, just as often, have personal campaign motives for blogging as challengers, and high party activity is positively correlated with such motives. Thus, even though ideology is important, it looks as if there is a degree of pragmatism involved in blogging, as well. Furthermore, when it comes to involvement in the blogosphere, there are some significant relationships. The data roughly indicate that actively reading and/or writing blogs is positively associated with support for a stronger personal

Table 2. Blogging and individualism; left and right (percentages)

\begin{tabular}{|c|c|c|c|c|c|c|c|c|c|}
\hline & \multicolumn{3}{|c|}{$\begin{array}{l}\text { Support "a stronger } \\
\text { personal vote" }\end{array}$} & \multicolumn{3}{|c|}{$\begin{array}{l}\text { Personal campaign } \\
\text { motif for blogging }\end{array}$} & \multicolumn{3}{|c|}{ Blog focusing on person } \\
\hline & Left & Right & Diff. & Left & Right & Diff. & Left & Right & Diff. \\
\hline All & 24 & 69 & $45^{* * * *}$ & 21 & 63 & $42^{* * * *}$ & 20 & 42 & $22^{* * * *}$ \\
\hline $\begin{array}{l}10 \text { party meetings } \\
\text { Less } \\
\text { Difference }\end{array}$ & $\begin{array}{c}21 \\
28 \\
7\end{array}$ & $\begin{array}{l}67 \\
75 \\
8\end{array}$ & $\begin{array}{l}46^{\text {*** }} \\
37^{* * *}\end{array}$ & $\begin{array}{c}26 \\
10 \\
-16^{*}\end{array}$ & $\begin{array}{l}73 \\
44 \\
-29^{* * *}\end{array}$ & $\begin{array}{l}47^{* * * *} \\
34^{* * *}\end{array}$ & $\begin{array}{l}18 \\
39 \\
21^{* *}\end{array}$ & $\begin{array}{c}42 \\
44 \\
2\end{array}$ & $\begin{array}{c}24^{* * *} \\
5\end{array}$ \\
\hline $\begin{array}{l}\text { Incumbent } \\
\text { Challenger } \\
\text { Difference }\end{array}$ & $\begin{array}{c}18 \\
31 \\
23^{*}\end{array}$ & $\begin{array}{c}64 \\
79 \\
15^{* *}\end{array}$ & $\begin{array}{l}46^{\text {**** }} \\
48^{\text {**** }}\end{array}$ & $\begin{array}{c}24 \\
25 \\
1\end{array}$ & $\begin{array}{c}70 \\
71 \\
1\end{array}$ & $\begin{array}{l}46^{* * * *} \\
46^{* * * *}\end{array}$ & $\begin{array}{c}19 \\
23 \\
4\end{array}$ & $\begin{array}{c}42 \\
43 \\
1\end{array}$ & $\begin{array}{l}23^{* * *} \\
20^{* * *}\end{array}$ \\
\hline $\begin{array}{l}\text { Left of party } \\
\text { Same as party } \\
\text { Right of party } \\
\text { Difference }\end{array}$ & $\begin{array}{c}17 \\
28 \\
22 \\
6\end{array}$ & $\begin{array}{l}63 \\
51 \\
74 \\
11\end{array}$ & $\begin{array}{l}46^{\text {*** }} \\
23^{\text {*** }} \\
52^{\text {*** }}\end{array}$ & $\begin{array}{c}19 \\
13 \\
25 \\
6\end{array}$ & $\begin{array}{l}69 \\
64 \\
62 \\
-7\end{array}$ & $\begin{array}{l}49^{\text {*** }} \\
51^{\text {*** }} \\
37^{\text {*** }}\end{array}$ & $\begin{array}{r}54 \\
37 \\
40 \\
-14\end{array}$ & $\begin{array}{c}52 \\
41 \\
52 \\
0\end{array}$ & $\begin{array}{c}-2 \\
4 \\
12^{* *}\end{array}$ \\
\hline $\begin{array}{l}\text { Short time blogger } \\
\text { Long time blogger } \\
\text { Difference }\end{array}$ & $\begin{array}{l}23 \\
20 \\
-3\end{array}$ & $\begin{array}{l}63 \\
74 \\
13^{*}\end{array}$ & $\begin{array}{l}40^{* * * *} \\
54^{* * *}\end{array}$ & $\begin{array}{l}36 \\
19 \\
-23^{* * *}\end{array}$ & $\begin{array}{c}70 \\
70 \\
0\end{array}$ & $\begin{array}{l}34^{* * * *} \\
46^{* * *}\end{array}$ & $\begin{array}{c}19 \\
21 \\
2\end{array}$ & $\begin{array}{l}38 \\
48 \\
10\end{array}$ & $\begin{array}{l}19^{* *} \\
27^{* * *}\end{array}$ \\
\hline Frequent blogger & 24 & 71 & $47^{* * *}$ & 20 & 63 & $43^{* * *}$ & 21 & 44 & $23^{* * *}$ \\
\hline $\begin{array}{l}\text { Infrequent blogger } \\
\text { Difference }\end{array}$ & $\begin{array}{l}18 \\
-6\end{array}$ & $\begin{array}{l}67 \\
-4\end{array}$ & $49^{* * *}$ & $\begin{array}{c}30 \\
-10\end{array}$ & $\begin{array}{c}77 \\
-14^{* *}\end{array}$ & $47^{* * *}$ & $\begin{array}{l}18 \\
-3\end{array}$ & $\begin{array}{l}40 \\
-4\end{array}$ & $22^{* * *}$ \\
\hline $\begin{array}{l}\text { Reading few blogs } \\
\text { Reading many } \\
\text { Difference }\end{array}$ & $\begin{array}{c}18 \\
41 \\
23^{* * *}\end{array}$ & $\begin{array}{l}66 \\
77 \\
11\end{array}$ & $\begin{array}{l}48^{* * *} \\
46^{* * *}\end{array}$ & $\begin{array}{l}15 \\
25 \\
10\end{array}$ & $\begin{array}{c}62 \\
72 \\
-10\end{array}$ & $\begin{array}{l}40^{* * * *} \\
46^{* * * *}\end{array}$ & $\begin{array}{l}23 \\
19 \\
-4\end{array}$ & $\begin{array}{l}48 \\
41 \\
-7\end{array}$ & $\begin{array}{l}21^{* * *} \\
23^{* * *}\end{array}$ \\
\hline $\begin{array}{l}>40 \text { years old } \\
<40 \text { years old } \\
\text { Difference }\end{array}$ & $\begin{array}{c}24 \\
24 \\
0\end{array}$ & $\begin{array}{l}59 \\
79 \\
20^{* *}\end{array}$ & $\begin{array}{l}35^{\text {*** }} \\
55^{\text {*** }}\end{array}$ & $\begin{array}{l}25 \\
17 \\
-8\end{array}$ & $\begin{array}{l}67 \\
58 \\
-9\end{array}$ & $\begin{array}{l}42^{* * *} \\
41^{* * *}\end{array}$ & $\begin{array}{l}24 \\
19 \\
-5\end{array}$ & $\begin{array}{c}40 \\
47 \\
7\end{array}$ & $\begin{array}{l}16^{* * *} \\
28^{* * *}\end{array}$ \\
\hline $\begin{array}{l}\text { Men } \\
\text { Women } \\
\text { Difference }\end{array}$ & $\begin{array}{l}24 \\
18 \\
-4\end{array}$ & $\begin{array}{c}75 \\
57 \\
-18^{* * * *}\end{array}$ & $\begin{array}{l}51^{* * *} \\
39^{* * *}\end{array}$ & $\begin{array}{c}21 \\
30 \\
9\end{array}$ & $\begin{array}{l}67 \\
75 \\
8\end{array}$ & $\begin{array}{l}46^{* * * *} \\
45^{\text {**** }} \\
\text { **** }\end{array}$ & $\begin{array}{c}19 \\
23 \\
4\end{array}$ & $\begin{array}{l}47 \\
35 \\
-12^{* *}\end{array}$ & $\begin{array}{c}28^{* * *} \\
12\end{array}$ \\
\hline $\begin{array}{l}\text { High education } \\
\text { Low education } \\
\text { Difference }\end{array}$ & $\begin{array}{l}22 \\
19 \\
-3\end{array}$ & $\begin{array}{l}63 \\
80 \\
14^{* * *}\end{array}$ & $\begin{array}{l}41^{* * *} \\
61^{* * *}\end{array}$ & $\begin{array}{l}26 \\
21 \\
-5\end{array}$ & $\begin{array}{l}72 \\
64 \\
-6\end{array}$ & $\begin{array}{l}46^{\text {**** }} \\
43^{\text {**** }}\end{array}$ & $\begin{array}{l}20 \\
19 \\
-1\end{array}$ & $\begin{array}{c}41 \\
43 \\
2\end{array}$ & $\begin{array}{l}21^{* * *} \\
24^{* * *}\end{array}$ \\
\hline $\mathrm{N}$ & 221 & 311 & & 247 & 342 & & 220 & 308 & \\
\hline
\end{tabular}


vote and a campaign motive for blogging, on both the left and the right. No significant relationships are found in relation to blog focus. However, it is interesting to note that long-time blogging means different things to the left and right. On the right, long-time bloggers are significantly more individualized (in their support for a stronger personal vote). On the left, long time-bloggers are significantly less individualized (in terms of their motives for blogging). It is, therefore, far from certain that the cumulative effect of blogging will push the leftist blogosphere towards a more individualized approach over time.

How about social characteristics? Are some groups - such as young, highlyeducated candidates - particularly likely to use blogs to individualize their campaigns? In general, the results show moderate differences between groups, indicating that the threshold for using blogs to conduct individualized campaigns is relatively low. Within the right, there are significant differences in relation to age, education and gender. Young and highly-educated bloggers are more supportive of a stronger personal vote than are older and less educated bloggers. Men are both more individually focused and motivated by personal campaign aspirations than are women. The fact that no age differences are found within the left-oriented group is interesting and suggests - in line with the argument above - a continuing divergence, rather than convergence, of the left and right blogospheres. There does not seem to be a younger generation of political bloggers on the left coming to age with more individualized attitudes to blogging and politics. Rather, young bloggers on the left appear to resemble their older colleagues, while individualism is amplified among young bloggers on the right.

\section{Conclusions}

In the popular debate on online campaigning, deterministic perspectives are at the center. The new opportunity structure of the internet is assumed to change everything or nothing at all. Institutional contexts make all the difference - or none. According to Wright [21], this deterministic framework often distorts how researchers make sense of their empirical findings by creating undue expectations. In the face of all the hyping of technology, there is danger of an implicit pessimistic mindset being adopted. Considering the institutional context in Sweden, with parties of unparalleled strength and an election system with limited incentives for candidate-centered campaigns, we should, thus, be careful not to set too-high expectations. It is important to note that a pretty large number of candidates blogged during the 2010 electoral campaign and that the blogging uptake has been quite broad. More than the usual number of pioneers have been blogging, and their blogs have often been used in candidatecentered campaigns. Furthermore, many bloggers perceive their blogs as having given them more influence, and the more they have been involved in the blogosphere, the more influence they report. Hence, the medium appears to be important.

The main conclusion to be drawn from this study is, nonetheless, that the uptake and usage of blogging, to a considerable degree, is mediated by ideology and party affiliation. First, blogs seem to be more attractive to politicians who stand to the right, both among and within parties. A possible explanation for this ideological asymmetry within the Swedish blogosphere lies in common understandings of blogging as an 
individualistic practice and, therefore, more attractive to politicians with liberal ideological convictions [5]. Second, we find that right-oriented bloggers are widely embracing political individualization, while bloggers on the left are more hesitant. As left-oriented politicians are socialized into collectivistic party organizations that have traditionally opposed reforms for a stronger preferential voting system and traditionally been characterized by stronger party loyalty, this duality is quite logical $[10,11$, $12,14]$. Within these parties, a wide support for a stronger preferential vote, as well as an increase in the number of blogs used for personal election campaigns and individually-focused blogs, would be nothing less than a landslide. Instead, we see the prevailing influence of preexisting party cultures that mediate the uptake, and use of political blogs. The available evidence does not suggest that further blog experience or the younger generation will automatically change this. The results therefore underline the importance for researchers to consider ideological frameworks as well as institutional contexts, in order to fully understand the differentiated impact of e-participation.

\section{References}

1. Wright, S.: Read my day? Communication, campaigning and councillors' blogs. Information Polity 13(1/2), 81-95 (2008)

2. Coleman, S.: The Blogs and the New Politics of Listening. Political Quarterly 76, 272-280 (2005)

3. Anstead, N., Chadwick, A.: Parties, election campaigning, and the Internet: toward a comparative institutional approach. In: Routledge Handbook of Internet Politics, pp. 56-71. Routledge, London (2009)

4. Zittel, T.: Political representation in the networked society: the Americanisation of European systems of responsible party government? Journal of Legislative Studies 9, 32-53 (2003)

5. Benkler, Y., Shaw, A.: A Tale of Two Blogospheres: Discursive Practices on the Left and Right. Berkman Center for Internet \& Society (2010)

6. Ekdale, B., Namkoong, K., Fung, T.K.F., Perlmutter, D.D.: Why blog? (then and now): Exploring the motivations for blogging by popular American political bloggers. New Media \& Society 12, 217-234 (2010)

7. Norris, P.: A virtuous circle: Political communication in post-industrial democracies. Oxford University Press, Oxford (2000)

8. Zittel, T.: Lost in Technology? Political Parties and the Online-Campaigns of Constituency Candidates in Germany's Mixed Member Electoral System. Journal of Information Technology and Politics 6, 298-311 (2009)

9. Katz, R.S.: The Problem of Candidate Selection and Models of Party Democracy. Party Politics 7, 277-296 (2001)

10. Esaiasson, P., Holmberg, S.: Representation from above: members of Parliament and representative democracy in Sweden. Aldershot, Dartmouth (1996)

11. Gilljam, M., Karlsson, D., Sundell, A.: Representationsprinciper i riksdag och kommuner. In: Folkets Representanter. Statistiska centralbyrån, Stockholm (2010)

12. Holmberg, S.: Riksdagen representerar svenska folket: empiriska studier i representativ demokrati. Univ., Göteborg (1974)

13. Möller, T.: The Swedish Election 1998: A Protest Vote and the Birth of a New Political Landscape? Scandinavian Political Studies 22, 261-276 (1999) 
14. Nielsen, P.: Ett decennium med personval: erfarenheter och utfall. Fritzes, Stockholm (2007)

15. Holmberg, S., Oscarsson, H.: Väljare: svenskt väljarbeteende under 50 år. Norstedts juridik, Stockholm (2004)

16. Katz, R., Peter, M.: How Parties Organize: Change and Adaptation in Party Organization in Western Democracies. Sage, London (1994)

17. Holmberg, S., Möller, T.: Premiär för personval: forskningsrapporter. Fakta info direkt, Stockholm (1999)

18. Gilljam, M., Karlsson, D., Sundell, A.: Politik på hemmaplan. In: Tiotusen svenska fullmäktigeledamöter tycker om politik och demokrati. SKL Kommentus, Stockholm (2010)

19. Persson, J., Öhrvall, R.: Förtroendevalda i kommuner och landsting 2007: en rapport om politikerantal och representativitet. Statistiska centralbyrån, Stockholm (2008)

20. Findahl, O.: Svenskarna och Internet 2010. World Internet Institute, Hudiksvall (2010)

21. Wright, S.: Political as usual? Revolution, normalisation and a new agenda for online deliberation. In: From e-Participation to Online Deliberation, Proceedings of the Fourth International Conference on Online Deliberation, OD 2010, Leeds (2011) 